\title{
Solutions to Challenges of Land Acquisition for Railway Developments
}

\author{
Hiroki Ito ${ }^{1}$ \\ ${ }^{1}$ MPP student at the Blavatnik School of Government, University of Oxford
}

\begin{abstract}
.
Railway developments have drastic effects on the economy and daily lives of citizens, and a large number of countries compete to make investments on them. One of the challenges of railway developments is land acquisition. It requires a long-period of negotiation and vast amounts of money, but at the same time, it often causes protests from affected inhabitants. Delays in land acquisition result in the suspension of projects and a loss of revenues. It is possible that inhabitants suffer from inhumane treatment from authorities to implement land acquisition. Therefore, it is necessary to explore solutions in order to implement land acquisition smoothly. This paper discusses significance and challenges of railway developments and land acquisition, and suggests the importance of 1) creating an independent organisation specialised in railway projects, 2) delivering benefits to those affected as incentives and 3) developing partnership between stakeholders. It analyses three cases in their process, evaluation and effects: 1) The Mumbai Urban Transportation Project (MUTP), 2) The Tsukuba-Express Line (TX) and 3) Crossrail. These cases are common in that they employed a new organisation, provided benefits to inhabitants and needed coordination with a large number of stakeholders. Through the case study, this paper aims to gain lessons and make recommendations. The recommendations are 1) establish a specialised organisation, 2) empower local communities, 3) combine railway developments with urban developments and 4) provide information for inhabitants.
\end{abstract}

Keywords: Independent organisation, partnership and coordination, empowerment, linkage between railway and urban developments, information provision

\section{Introduction}

Recently countries have been eagerly investing a fortune in constructing or improving large-scale infrastructures such as high-speed railways and railroads. India, for example, has been constructing a high-speed railway between Mumbai and Ahmadabad to promote domestic transportation and international investment. They are regarded as huge projects to affect the whole countries in the long run, so they must be implemented carefully. The development of a new railway tends to require a great deal of land and, therefore, large-scale land acquisition is inevitable in those cases. However, the process of land acquisition involves various issues, so it is necessary to analyse the problems and seek solutions while considering each citizen and protecting human rights. 


\section{Significance and challenges of railway developments}

\subsection{Significance}

Transportation systems to transfer exports to neighbouring countries could enable landlocked countries in Africa to alleviate severe poverty (Collier, 2007). In addition to high-speed railways and railroads, other forms of infrastructure such as pipelines to transport fuel could increase total welfare in the nation (Hector M Nunez, Hayri Onal and Madhu Khanna, 2012). Furthermore, large-scale infrastructures contribute to people in other fields than the economy: a road effectively functions also as a conduit for carrying energy, water and telecommunications under it (Marvin and Slater, 1997).

\subsection{Challenges}

Looking at the other side of the discussion, a lot of research explains problems concerning the acquisition or management of land by the government. Local people's massive protests against a land reform policy led by the government took place in Brazil (Alston et al., 1999). Governments tend to oppress people in the course of expropriation (Alyssa, 2006). Moreover, developmental issues and land acquisition cover too wide a range of areas for one local government alone to cope with (Balakrishnan, 2013). Therefore, it is essential to seek solutions to the challenges of expropriation in order to reduce discontent among concerned inhabitants and then proceed with projects more smoothly.

The first challenge to be discussed is that local inhabitants may hesitate to and refuse to leave away from their current houses and these cases are possible to result in the delay of projects. In the case of Karachi Circular Railway's improvement project, some people firmly resisted and rejected expropriation, which is one reason why the project has not finished yet although it was launched around 2000 (Hasan, 2009). Also, it is often the case in Brazil that people resort to violence in protest movements against land acquisition which the federal government attempts (Alston et al., 1999).

The next problem to be elaborated is that people involved in expropriation are vulnerable to unethical treatments from governments. Eviction is sometimes carried out forcefully before the content of local inhabitants is fully reached, which puts them into harsh circumstances. In some countries such as Zimbabwe, Peru and Cambodia, there are many cases where it is not until people are pulled out of their house that they learn about the eviction (Alyssa, 2006). The governments there seem reluctant to prepare alternative houses and legal systems to retrieve the properties. Moreover, even though Brazil has a system to allocate alternative settlement to landless farmers in the course of expropriation, most farmers find that their desire will be barely met and that they will have to wait long until the new land is assigned (Alston et al., 1999).

The last issue to be discussed is that as the development of large-scale infrastructures and land acquisition tend to matter on a large scale beyond boundaries of municipalities, a local government alone does not fully function to solve those problems. Local governments in India are not able to manage trans-local developments along highways (Balakrishnan, 2013). Furthermore, minor governments are financially weak and vulnerable to influences from external organizations such as central governments and private developers (Audefroy, 1994).

\subsection{Discussion}




\section{$10^{\text {th }}$ INTERNATIONAL CONFERENCE ON MANAGEMENT , ECONOMICS AND HUMANITIES}

(1) Values of large-scale infrastructures

It is valid to claim that constructing large-scale infrastructures can realize long-term prosperity, especially in developing countries. Those projects are expected to be worth implementing while overcoming their challenges.

\section{(2) Actors and method involved in land acquisition (Process)}

As central governments may hardly know in detail about each local area and local governments are not likely to be powerful enough to complete the land acquisition, it is expected that multiple actors will work together and contribute to projects. Looking at the process of land acquisition can help us think about how land acquisition should be implemented. Especially, it is suggested that an independent organisation which are jointly created by local governments and work across boundaries like upper governments because this organisation is equipped with advantages of both types of governments.

(3) Advantages of land acquisition projects (Evaluation)

House and landowners should be relieved from the weaker position and be treated in more conciliatory ways. At the same time, authorities must complete land acquisition to develop infrastructures. The point of the argument is the balance between the two parties. Therefore, it is valuable to clarify what advantages and disadvantages of land acquisition projects have.

(4) Merits provided for stakeholders (Effects)

As inhabitants easily recognize those risks caused by land acquisition, it is quite natural for local inhabitants to stick to their house and disagree with projects. At the same time, however, it is necessary to persuade and compromise with them in order to achieve the construction of large-scale infrastructures. Providing a form of merits such as compensation or something equivalent to it is expected to work as an incentive, so it is paramount to explore what effects projects have given to stakeholders. In railway projects, which often matter to various municipalities and people, it is crucial to establish coordination and partnership and to keep the balance between stakeholders.

(5) What this paper does

The literature review highlights the importance of 1) an independent organisation to coordinate multiple concerned parties in land acquisition, 2) involvement of local inhabitants and 3) providing a return of land acquisition for stakeholders. This paper explores 1) roles of the infleppebdentorganjisations, 2) the significance of inhabitant involvement in land acquisition and 3 ) advantages given to stakeholders. It analyses three significant projects from the perspective of their process, evaluation and effects to gain lessons about land acquisition and to make a political recommendation. All the cases employed a new organisation, needed coordination with a large number of stakeholders and involved local inhabitants (Tab.1). 


\begin{tabular}{|c|c|c|c|c|}
\hline \multirow{2}{*}{ Case } & \multicolumn{2}{|c|}{ An authority } & \multirow{2}{*}{ Stakeholders } & \multirow{2}{*}{ Inhabitant involvement } \\
\hline & Name & Founders & & \\
\hline MUTP & $\begin{array}{l}\text { The Mumbai Railway } \\
\text { Vikas Corporation }\end{array}$ & $\begin{array}{l}\text { - The state corporation } \\
\text { - The Indian Railways }\end{array}$ & $\begin{array}{l}\text { - The government of Maharashtra } \\
\text { - The Indian Railways } \\
\text { - The municipal corporation of Greater Mumbai } \\
\text { - Inhe British Mumbai Electric Supply Undertaking } \\
\text { - Inhants including slums dwellers }\end{array}$ & Empowered local communities \\
\hline$T X$ & $\begin{array}{l}\text { Metropolitan } \\
\text { Intercity Railway } \\
\text { Company }\end{array}$ & $\begin{array}{l}\text { - Concerned prefectures } \\
\text { and municipalities }\end{array}$ & $\begin{array}{l}\text { - Inhabitants, } \\
\text { - Local governments } \\
\text { - Real estate companies } \\
\text { - Urban Renaissance Agency }\end{array}$ & $\begin{array}{l}\text { Urban development and house } \\
\text { provision } \\
\text { combined with railway } \\
\text { construction }\end{array}$ \\
\hline Crossrail & $\begin{array}{l}\text { Cross London Rail } \\
\text { Links }\end{array}$ & $\begin{array}{l}\text { - The Strategic Rail } \\
\text { Authority } \\
\text { - Transport for London }\end{array}$ & $\begin{array}{l}\text { - Inhabitants in central London } \\
\text { - The Strategic Rail Authority } \\
\text { - Transport for London }\end{array}$ & $\begin{array}{l}\text { Information provision and } \\
\text { communication }\end{array}$ \\
\hline
\end{tabular}

\section{The Mumbai Urban Transportation Project (MUTP)}

\subsection{Case overview}

MUTP is a project to strength railways in Mumbai to improve the city's traffic situation. It consists of three phases, and among them, this report deals with MUTP 1, which started at the beginning of this century. The project included new railway construction, station platform expansion, railway crossing removal, and resettlement of households living within 10 metres of the tracks. It was expected to lead to an increase in rail capacity, a reduction in travel time and improved management of passenger and vehicle flow (Patel et al., 2002). Consequently, 15,000 households along the tracks and 4,000 households around the station in the so-called "railway slums" were involved in the involuntary resettlement.

\subsection{Process of land acquisition}

The Mumbai Railway Vikas Corporation implemented the MUTP project, co-founded by the state corporation and the Indian Railways. Also, a residential community called the Railways Slum Dwellers Federation (NSDF) contributed to the resettlement by data collection and mapping, establishing women's savings and credit group, and promoting the formation of housing cooperative societies (Patel et al., 2002).

In 1999, resettlement sites were developed providing permanent dwellings and transit accommodation, as the first step towards full implementation. About 60,000 people were resettled in just over a year without the use of any municipal or police force.

In 2001, however, the Indian Railway demolished over 2,000 huts along the railway line, which were deemed to have violated state government policy and the stipulations of MUTP. It is likely that this coercive eviction proceeded partly due to media pressure, resulting in an urgent need to accommodate the 2,000 evicted families. The resident alliance had discussions with the World Bank and reached an agreement which enabled the residents to build transit accommodation with fewer costs, which was occupied within a few months.

\subsection{Evaluation}

The interviews and group discussions have revealed a general approval among the residents of the relocation (Patel et al., 2002). The resettlement was successful, being facilitated by well-established community organizations. Households were organized before the resettlement based on survey results on the population affected, which also helped to inform the allocation of 


\section{$10^{\text {th }}$ INTERNATIONAL CONFERENCE ON MANAGEMENT , ECONOMICS AND HUMANITIES}

accommodation on the resettlement sites. In this sense, the implementation of the project can be said to be a community-driven process.

On the other hand, the developers in the MUTP project faced several common challenges in land acquisition projects, including maintaining public facilities and essential infrastructure services, as well as the impact on the local community (Patel et al., 2002). Purchasing and developing new structures on public land involves the risk of restricting access to public facilities such as hospitals, post offices, and schools. Additionally, people who work close to home may be forced to change their occupations because of the resettlement. A further influence on the societal level may also be observed, as the relocated community members will have to build new relationships. Therefore, despite the economic gains from large infrastructure projects, residents have good reasons to be concerned about their potential regional effects.

\subsection{Effects}

(1) Enabled smoother land acquisition through organised local communities

The case suggests that local organisations are effective in advancing land acquisition. Without the organisation, it would have been less like likely that local inhabitants delivered their demands and opinions to authorities because individual inhabitants are so weak that authorities accept their demands. On the other hand, authorities.

(2) Improved living standard

The resettlement improved the living standard of the original slum inhabitants by providing secure better-quality accommodation with piped water, sanitation, and electricity (Patel et al., 2002).

(3) Self-governance of inhabitants

In the settlements, inhabitants worked together to improve their lives as a community (Patel et al., 2002). For example, ration shops were set up as community cooperatives to offer daily necessities at low prices, and committees were organized to manage water, sanitation, and garbage. These bottom-up approaches have resulted in a high level of self-governance and minimized their dependence on state and municipal governments.

\section{The Tsukuba-Express Line (TX)}

\subsection{Case overview}

TX is a $58.3 \mathrm{~km}$-long high-speed railway connecting Akihabara in Tokyo and Tsukuba City in Ibaraki Prefecture, and it started its operation in August 2005. It aims for development in a broad sense, including improving transportation system of the Tokyo metropolitan area and alleviating congestion of existing lines, as well as providing a large number of high-level 


\section{$10^{\text {th }}$ INTERNATIONAL CONFERENCE ON MANAGEMENT , ECONOMICS AND HUMANITIES}

houses and creating foundations for industries along the line. One of its guiding policies was to connect the new line with the existing lines to ensure consistency with regional development.

\subsection{Process of land acquisition}

TX was launched in the late 1980', when "Private Sector Resources Utilization Law" and "Capital Reform Project" mentioned the necessity of easing congestion of "Joban Line" running almost parallel to TX (Inui, 2016; Ogawa, 2018). Afterwards, in 1989, the Japanese government enacted a law named "Act on Special Measures concerning Comprehensive Advancement of Housing Development and Railway Construction in Metropolitan Areas", which called for close cooperation among concerned municipalities, railway companies and the national government on the planning of urban areas and railways. In particular, it initiated "integrated land readjustment projects" to facilitate the acquisition of railway land (Inui, 2016).

In these projects, railway companies and local municipalities were given a pre-emption right to purchase and to exchange the land with the prescribed railway land. In order to promote the plan, local governments along with TX jointly capitalised a third-sector company named "Metropolitan Intercity Railway Company, MIR" in 1991. East Japan Railway Company, which was expected to be a business operator at first, declined to construct a new line there, so the third sector and "Urban Renaissance Agency", an Incorporated Administrative Agency, played roles in purchasing land. The system made it possible to secure efficient railway land acquisition and was expected to shorten the project term and integrate the development of urban areas and railways. It also allowed the provision of public facilities including roads and parks in a planned and integrated way. To sum up, the development alongside TX was empowered by a legal framework, and local governments expecting increases in demand for houses worked together closely (Inui, 2016).

\subsection{Evaluation}

The developers of the TX project tended to hold a positive view of the integrated development of the urban area and railways, referring to the fact that the construction of stations led to an increase in land prices and facilitated urban development (Takatsu et al., 2006).

To the contrary, a problem concerning consensus formation arose. Compared with the situation involving only railway land purchase, this land acquisition mode necessitated a consensus among a vast number of landowners (Takatsu et al., 2006). Therefore, barriers were inevitable in seeking consensus on the project despite its benefits. In fact, in some municipalities, inhabitants protested against the project as they concerned about the effect of land exchange on agriculture and the burden of increased taxes. In their attempts to seek consensus, the municipal governments agreed to increase subsidies after conducting consecutive meetings.

\subsection{Effects}

(1) Integrated development

Railway-associated facilities such as squares near stations were developed alongside the railway. Commercial facilities, educational institutions and medical and welfare institution along TX allow local inhabitants to lead a more convenient life (Ogawa, 2018). Especially, 


\section{$10^{\text {th }}$ INTERNATIONAL CONFERENCE ON MANAGEMENT , ECONOMICS AND HUMANITIES}

large-scale commercial facilities and residential sections are allocated separately in a carefully planned way (Tanno et al., 2009). At the same time, a rich natural environment is conserved, and a wide area of rural zones can be seen along with TX (Ogawa, 2018). "Act on Special Measures concerning Comprehensive Advancement of Housing Development and Railway Construction in Metropolitan Areas" closely connected regional development with the construction of railways.

(2) A new local society in rural areas

TX is characteristic of an integrated development mode in that its construction involved the development of extensive areas and several municipalities along the line of the high-speed railway (Takatsu et al., 2006). That contributed to the creation of a variety of local society in rural areas based on the history and culture of each district having multiple functions, including academism. Ibaraki Prefecture, for example, provides suburban houses where people have easy access to nature and agriculture. As a result, the number of people living in municipalities along with TX and the number of commuters of TX has been steadily increasing since it began operation (Ogawa, 2018; Takatsu et al., 2006).

(3) Inter-city connection

The research and educational institutions in cities along TX were connected by railways. TX enables them to foster coordination and work together (Takatsu et al., 2006).

\section{Crossrail}

\subsection{Case overview}

Crossrail, also known as the Elizabeth line, started its construction in 2009 and it is going to run beneath London from Reading and Heathrow in the west through central tunnels across to Shenfield and Abbey Wood in the east. The railway involved $42 \mathrm{~km}$ of new tunnels and ten new stations and needed to acquire around 13,000 land and property (Grujic, 2018). The route includes economically and historically essential districts in London (Lindsay, 2018), so there are a large number of stakeholders concerned.

Crossrail was expected to start its full operation by December 2018 (BBC, 23 November 2018). However, some parts of them are yet to be completed in 2020, and it has been criticised for its delay and also over-budgeting (BBC, 24 Mar 2020; BBC, 21 July 2020). The delay and over-budgeting are attributed to its complex testing of signalling systems (BBC, 24 July 2018; BBC, 31 August 2018), so land acquisition did not affect the progress of the plan.

\subsection{Process of land acquisition}

The Crossrail programme was authorised by "the Crossrail Act 2008". The development of Crossrail is planned by Cross London Rail Links (CLRL), a joint venture between The Strategic Rail Authority and Transport for London (Bennett, 2017). The process of land acquisition for Crossrail is characterised by CLRL's communication with stakeholders and the existence of experts. 


\section{$10^{\text {th }}$ INTERNATIONAL CONFERENCE ON MANAGEMENT , ECONOMICS AND HUMANITIES}

In 2002, CLRL organised a Public Affairs department, which is in charge of its communications and consultation with stakeholders. In 2003, the Department for Transport (DfT) asked CLRL to conduct public consultation (Bennett, 2017). Before the public consultation, CLRL established objectives for the consultation to identify stakeholders and their concerns, and led a 'public awareness' campaign, prompting people to express their interest (Bennett, 2018).

This consultation programme included establishing a helpdesk and a stakeholder database and holding information centres. The helpdesk was launched to create opportunities for a wide range of people to enquire about the project (Bennett, 2018). The stakeholder database recorded people who reached out, and information and responses which they received. The most crucial purpose of the database is to ensure that the history of communication can be used to answer other enquiries (Bennett, 2018). The information centres were built along the route, close to proposed stations or significant works (Bennett, 2017). Engineers, planners and environment specialists joined the consultation team to answer detailed questions.

\subsection{Evaluation}

Specialists working at information centres were helpful to address matters of concern (Bennett, 2018) directly. With support from the consulting team, the experts used briefings to explain the plan to stakeholders in a more intelligible way, confirmed that the plan was correctly understood, ensured that likely impacts were evaluated accurately, and informed them that all proposals were possible to change due to the consultation and further work.

Although there were 1,600 or more claimants, the final costs for land acquisition are anticipated to be $1 \%$ below budget (Lindsay, 2018). One of the reasons for this outcome is that CLRL and Transport for London (TfL) employed sophisticated project and programme management tools (Lindsay, 2018).

\subsection{Effects}

(1) Increases in transport capacities in London

It is estimated that approximately 200 million passengers will use Crossrail every year (BBC, 31 August 2018). Crossrail will increase rail capacity in central London by 10\%, which is the most massive increase since the Second World War.

(2) Less traffic congestion in and around London

Crossrail will mitigate chronic congestion in London by connecting essential sites such as Heathrow Airport and the Canary Wharf business district (BBC, 31 August 2018).

\section{(3) Analysis of responses of consultees}

The team reviewed responses of consultees in terms of such as whether they agreed, whether they had positive or negative views on environmental impacts and transport capacity, and what comments they had on the route (Bennett, 2018). Based on the outcomes, a report was compiled, and it was presented and circulated in the team. 


\section{Results: lessons and discussion}

\subsection{Process}

All the cases created an independent organisation specialised in railway projects to initiate land acquisition. These organisations can be said to have helped concerned authorities cooperate and coordinate with each other. Their expertise enabled land acquisition to be implemented more smoothly. The larger number of institutions and companies join the organisations, the more difficult it will become to retain partnership within the organisations. Private sectors, such as consultant companies should be incorporated into partnership. One of the challenges is how to keep balance and coordination between stakeholders, so these organisations are expected to work independently from stakeholders.

Independent organisations were influential in persuading local inhabitants who will be affected by railway construction to compromise on land acquisition. Benefits tend to be more elusive than damages, and they are sensitive to immediate changes in their daily life, so it is of great importance give them a sense of relief by explaining likely results and providing blueprints of the plan. Independent organisation can function as a unified consultant and foster communication with local inhabitants.

\subsection{Evaluation}

The cases are generally favourably received by inhabitants or media. These responses show that providing benefits can raise the likelihood of successfully acquiring land and that it is valid to avoid forcible approaches such as eviction and violence.

Railway projects often matter across boundaries of municipalities. This tendency is positively evaluated in activating movements of people on a larger scale, but at the same time, it highlights the difficulty of coordination. As various stakeholders are concerned, it becomes harder to reach consensus; different municipalities and people have different values, preference and priorities. It is not easy to make all parties better-off, so the challenge is to give damage to as few people as possible and to minimise damage.

\subsection{Effects}

Legal evidence and authority supporting plans are crucial to implementing them successfully. In the context of land acquisition, organisations responsible for it should be granted legally defined roles and authority. It is also paramount to legally connect regional developments with railways themselves in laws, which will incorporate railways into urban structures and increase commuters and revenues.

Especially in developing countries, railway developments can work as an opportunity to enhance living standards by providing piped water, sanitation, and electricity. This effect can be explained by the tendency of railway developments to entail drastic changes in urban structures. Likewise, developments are likely to empower and enlighten people by promoting them to create local organisations and to think about how their community should be. To utilise railway developments as a great chance of renovating cities, plans must be carefully formulated considering long-term effects. 


\section{Recommendations}

\subsection{Establish a specialised organisation}

A specialised organisation in railway projects should be established. It can implement land acquisition more smoothly and coordinate concerned parties with expertise. Its existent will make the process more integrated and more straightforward, which otherwise could be complicated. A more comprehensive range of parties should be included, such as consulting firms and private railway companies. It is better to give a legal foundation and clearly define its responsibilities and functions.

\subsection{Involve inhabitants}

\section{(1) Empower local communities}

Stronger communities are able to protect inhabitants from inhumane treatments which could be involved in land acquisition, and make more likely that authorities will accept their demand. Another merit is that those communities are expected to simplify the governmental process by offering a unified representative for negotiation instead of numerous individual inhabitants.

Since local organizations in Pakistan are legitimate under the Societies Act, they have a legal position and are allowed to negotiate with governments (Hasan, 2009) notes that. Considering that they actively participate in the negotiation, giving them legal status is beneficial in involving more inhabitants and shaping stronger organizations. Moreover, it would be effective to set categories in advance according to some criteria such as district, sex or occupation and make it a rule to elect at least one representative from each category when the necessity of land acquisition there emerges. This policy could make it easier to create organizations and reflect opinions from all social groups.

(2) Combine railway developments with urban developments

Urban developments along railway lines are likely to provide merits both for inhabitants, operators, and local governments. They will increase people's accessibility to public transport and then create more convenient lifestyles. They also increase local population and vitalise activities, raising fare yields and tax revenues. These noticeable returns can work incentives to persuade stakeholders into projects.

The example of TX can be used in this context. It suggests that setting up a legal framework is a powerful tool to link railway developments and urban developments. The legal framework is expected to create budgetary and technical measures for operators and to an established political position to the project.

(3) Provide information for inhabitants

Accurate and timely information eases anxiety and criticism which inhabitants tend to have and improve their images of railway developments in a democratic way. It is crucial to increase accessibility to information by creating as many channels and opportunities as possible.

Consultation programmes including a helpdesk, a stakeholder database and information centres, which were employed in Crossrail, shows an example to deliver information to every inhabitant. Financial and human resources for the consultation programme should be included in projects. 


\section{$10^{\text {th }}$ INTERNATIONAL CONFERENCE ON MANAGEMENT , ECONOMICS AND HUMANITIES}

\section{Conclusion}

This paper discussed the significance and challenges of railway developments and analysed three cases of land acquisition in terms of their process, evaluation and effects. It highlighted the importance of creating a specialised organisation with expertise which will establish the partnership between multiple actors, and trying to persuade people. It also adds the significance of setting out legal evidence for land acquisition. Moreover, it claims involving inhabitants into the process of land acquisition and exemplifies three measures.

\section{References}

[1] Paul, C. (2007), The Bottom Billion, Oxford University Press, the UK: Oxford

[2] Hector, M. N., Hayri, O. and Madhu, K. (2012) "A prospective analysis of Brazilian biofuel economy: land use and infrastructure development”, 2012 Conference, August 18-24, 2012, Foz do Iguacu, Brazil 126811, International Association of Agricultural Economists

[3] Simon, M. and Simon, S. (1997), Urban Infrastructure: The Contemporary Conflict Between Roads and Utilities, Pergamon, the UK: Oxford

[4] Lee, J. A., Gary, D. L. and Bernardo, M. (1999) "A model of rural conflict: violence and land reform policy in Brazil", Environment and Development Economics, Volume 4, Issue 2, pp. $135-160$

[5] Misner, A. (2006), "Eviction Noticed", Amnesty International Social Science Premium Collection, Volume 32, Issue 3, pp. 5

[6] Sai, B. (2013) "Highway Urbanization and Land Conflicts: The Challenges to Decentralization in India", Pacific Affairs, Volume 86, Issue 4, pp. 785-811

[7] Arif, H. (2009) "Land, CBOs and the Karachi Circular Railway", Environment \& Urbanization, Volume 21, Issue 2, pp. 331-345

[8] Joel, A. (1994) "Eviction trends worldwide - and the role of authorities in implementing the right to housing", Environment \& Urbanization, Volume 6, Issue 1, pp. 8-24.

[9] Patel, S., d'Cruz, C., \& Burra, S. (2002). "Beyond evictions in a global city; people-managed resettlement in Mumbai”, Environment \& Urbanization, Volume 14, Issue 1, pp. 159-172.

[10] Yasuyo, I. (2016) "The Details and Characteristics of Residential Development alongside Tsukuba Express Railway - Examination of 21 Century's Suburban Development-", Bulletin of the Faculty of Education, Ibaraki University. Humanities and social sciences, No 6, pp. 35-50

[11] Takeshi, O. (2018) "The process and effect of urban development on the Tsukuba Express Line -A case study of the urban development on the Tsukuba Express Line of Chiba Prefecture-", Reports of City Planning of Japan, No. 16, pp. 361-366 


\section{$10^{\text {th }}$ INTERNATIONAL CONFERENCE ON MANAGEMENT , ECONOMICS AND HUMANITIES}

[12] Toshiji, T., Jun, H., Hiroshi, H., \& Keiichi, S (2006) "A study on measures for the harmonization of construction of the Tukuba-Express Line and urban planning" Infrastructure planning review No.23, pp. 635-640

[13] Yasuhiko. T., Daisuke, K., Yuki H., and Seiji, K. (2009) "Reginal Changes along "Tsukuba Express" in Tsukuba City, Ibaraki prefecture", Geographical Space, Volume 2, Issue 1, pp. 51-62

[14] Milena, G. (2018). WORKFLOWS FOR MANAGING LAND AND PROPERTY INFORMATION. Crossrail Learning Legacy. 〈Online>. Available:

https://learninglegacy.crossrail.co.uk/documents/workflows-managing-land-property-infor mation/

[15] Ian, L. (July 2018). LAND ACQUISITION FOR CROSSRAIL. Crossrail Learning Legacy. <Online>. Available:

https://learninglegacy.crossrail.co.uk/documents/land-acquisition-for-crossrail/

[16] BBC NEWS. (2018, 23 November). Crossrail: National Audit Office to investigate delay and rising costs. BBC. https://www.bbc.co.uk/news/uk-england-london-46316587

[17] Thomas, M. (2020, 24 Mar). Work on Crossrail project suspended. BBC. https://www.bbc.co.uk/news/topics/c2qlxx5ze9xt/crossrail

[18] BBC NEWS (2020, 21 July). Crossrail: An extra £140m need to complete surface line. BBC.

https://www.bbc.co.uk/news/uk-england-london-53483675?intlink_from_url=https://www .bbc.co.uk/news/topics/c2qlxx5ze9xt/crossrail\&link_location=live-reporting-story

[19] BBC NEWS. (2018, 24 July). London's Crossrail project running £600m over budget. BBC. https://www.bbc.co.uk/news/uk-england-london-44942322

[20] BBC NEWS. (2018, 31 August). Crossrail delay: New London line will open in autumn 2019. BBC. https://www.bbc.co.uk/news/uk-england-london-45367990

[21] Simon, B. (2017) “Crossrail project to deliver London's Elizabeth line: from options to parliamentary bill”, Civil Engineering, Volume 170, Issue CE6, pp. 3-9

[22] Simon, B. (March 2018). ORGANISING THE CROSSRAIL CONSULTATION PROGRAMME. Crossrail Learning Legacy. <Online>. Available:

https://learninglegacy.crossrail.co.uk/documents/organising-crossrail-consultation-progra mme/ 